This page intentionally left blank 


\title{
August I9I4
}

France, the Great War, and a Month That Changed the World Forever

\author{
BRUNO CABANES \\ Translated by Stephanie O'Hara
}

Yale

UNIVERSITY PRESS

New Haven and London 
Published with assistance from the Kingsley Trust Association Publication Fund established by the Scroll and Key Society of Yale College.

English translation (C) 2016 by Yale University. Translated 2016 by Stephanie O'Hara.

Originally published as Aô̂t I4. (C) Éditions gallimard, Paris, 2014. Map by Bill Nelson.

All rights reserved.

This book may not be reproduced, in whole or in part, including illustrations, in any form (beyond that copying permitted by Sections 107 and Io8 of the U.S. Copyright Law and except by reviewers for the public press), without written permission from the publishers.

Yale University Press books may be purchased in quantity for educational, business, or promotional use. For information, please e-mail sales.press@yale. edu (U.S. office) or sales@yaleup.co.uk (U.K. office).

Set in Janson Roman type by IDS Infotech, Ltd. Printed in the United States of America.

Library of Congress Control Number: $201595953^{2}$ ISBN 978-0-300-20827-6 (hardcover : alk. paper)

A catalogue record for this book is available from the British Library.

This paper meets the requirements of ANSI/NISO Z39.48-I992 (Permanence of Paper).

Io $98765432 \mathrm{I}$ 